\title{
Falsyfikat dokumentu rzekomo z 1150 r. i jego transumpt z 1251 r.
}

Dokument wystawiony rzekomo przez Kazimierza Sprawiedliwego w $1150 \mathrm{r}$. dla klasztoru w Lądzie zachował się jedynie w transumpcie z $1251 \mathrm{r}$. wystawionym w Kramsku przez Kazimierza Konradowica ${ }^{1}$, który przekazuje nam jednak tylko tekst samej dyspozycji dyplomu rzekomo z 1150 r., pomijając pozostałe formuły dyplomatyczne. Zawiera nadanie dwóch wsi: Kłobii i Chocenia wraz z przypisaną do nich ludnością, której obowiązki i powinności względem klasztoru określa tzw. instruktarz ${ }^{2}$ oraz pełny immunitet ekonomiczny i sądowy. Natomiast transumpt Kazimierza Konradowica zachował się w oryginale.

Jak dotąd $\mathrm{w}$ dokumencie rzekomo z $1150 \mathrm{r}$. widziano jedynie grube fałszerstwo, toteż nie wzbudził szerszego zainteresowania w naszej historiografii i choć był już kilkakrotnie omawiany, to zawsze na marginesie innych zagadnień, nie doczeka1 się więc osobnego studium. Na ocenie tego dyplomu zaważyła z pewnością opinia wyrażona przez tej miary dyplomatyków, co Franciszek Piekosiński i Wojciech Kętrzyński ${ }^{4}$. Obaj w swoim sądzie byli zgodni, że książę Kazimierz Sprawiedliwy w 1150 r. nie był księciem udzielnym, nie mógł więc dokonywać jakichkolwiek nadań. W konsekwencji obaj podejrzewali i sam transumpt, nie wypowiadając

${ }^{1}$ Tak też został wydany w: Kodeks dyplomatyczny Wielkopolski, t. 1, Poznań 1877 [dalej: KDW dla tomów 1-4], nr 298.

2 Jest to określenie H. Łowmiańskiego, Początki Polski. Polityczne i społeczne procesy ksztattowania się narodu do początku wieku XIV, t. 6, cz. 1, Warszawa 1985, s. 302, przyp. 704.

${ }^{3}$ F. Piekosiński, Uwagi do Kodeksu dyplomatycznego Wielkopolski, „Przegląd Krytyczny” 1877 , t. 12 , s. 448 i n.

${ }^{4}$ W. Kętrzyński, Studia nad dokumentami XII wieku, „Rozprawy Akademii Umiejętności. Wydział Historyczno-Filozoficzny” 1891, t. 26, s. 86. 
jednak przeciw niemu żadnych argumentów. Kętrzyńskiemu wydało się podejrzane jedynie to, że książę Kazimierz Konradowic potwierdził dokument, który był nimia vetustate contritium, oraz możliwość potwierdzenia tak wydawałoby się oczywistego fałszerstwa. Dopiero Zofia Kozłowska-Budkowa ${ }^{5}$ wzięła w obronę dokument księcia Kazimierza Konradowica, poddając analizie jego stronę paleograficzną i stwierdziwszy, wprawdzie z pewnym wahaniem, współczesną dacie konfirmacji rękę, uznała go za autentyk. Oceny tej nie zmieniał odnotowany przez tę badaczkę fakt zredagowania transumptu przez cystersów lędzkich. Jednocześnie ugruntowała ona ocenę dokumentu rzekomo z 1150 r., dodając jednak, że wzmianka dokumentu potwierdzającego o złym stanie dokumentu potwierdzanego, która wzbudziła podejrzenia Kętrzyńskiego, nie jest niczym niezwykłym, wręcz przeciwnie - przedstawienie do konfirmacji zniszczonego dyplomu ułatwiało zadanie fałszerzowi.

Nieco bardziej gruntownie przeanalizował te dokumenty Józef Mitkowski ${ }^{6}$ przy okazji rozważań nad kancelarią Kazimierza Konradowica. Podtrzymał sąd Kozłowskiej-Budkowej na temat autentyczności transumptu z 1251 r., wykazując dowodnie rękę kancelaryjną pisarza Józefa ${ }^{7}$. Jednocześnie Mitkowski powtórzył wszystkie argumenty wypowiedziane przeciw dokumentowi rzekomo z $1150 \mathrm{r}$. Odnotuję, że poglądy te w niezmienionej postaci utrzymały się od czasów Piekosińskiego i Kętrzyńskiego do dziś. Ostatnio podejmowane próby ponownych badań nad rzekomo najwcześniejszymi dokumentami klasztornymi nie wniosły jednak niczego nowego do krytyki dokumentu Kazimierzowego ${ }^{8}$. Jedynie Tomasz Ginter zajął się szczegółowym rozbiorem obowiązków i powinności mieszkańców wsi klasztornych wymienionych na omawianym dokumencie, co wcześniej zrobił Stanisław Trawkowski ${ }^{9}$, do których wyników analizy wkrótce powrócę.

Konkludując stan badań nad dokumentem rzekomo z 1150 r., warto zauważyć, że pomimo trafności wcześniejszych ustaleń nie wyczerpują one problematyki tego fałszerstwa, bowiem dotychczasowe badania nie wychodzą poza elementarną krytykę autentyczności. Co więcej, odczuwa się pewną rezygnację w podejściu do

${ }^{5}$ Z. Kozłowska-Budkowa, Repertorium polskich dokumentów doby piastowskiej, Kraków 1937, s. $57-58$.

6 J. Mitkowski, Kancelaria Kazimierza Konradowica księcia kujawsko-łęczyckiego (12321267), Wrocław 1968, s. 29-31.

7 Tzw. ręka k3.

${ }^{8}$ H. Waraczewski, Proces fundacyjny klasztoru cystersów w Lądzie nad Warta, „Nasza Przeszłość" 1994, t. 83; A.M. Wyrwa, Procesy fundacyjne klasztorów cysterskich linii altenberskiej, Poznań 1995; T. Jurek, Dokumenty fundacyjne opactwa w Ladzie, „Roczniki Historyczne” 2000, t. 66 , s. $17-18$.

9 T. Ginter, Działalność fundacyjna Mieszka III Starego, Kraków 2008, s. 110-114; S. Trawkowski, Gospodarka wielkiej własności cysterskiej na Dolnym Ślasku w XIII wieku, Warszawa 1959, s. 111-113, 132-138. 
omawianego dyplomu spowodowaną okolicznością, że dokument rzekomo z $1150 \mathrm{r}$. zachowany w transumpcie nie zawiera formuł dyplomatycznych, uniemożliwiając, jakby się wydawało, tradycyjną krytykę. Jednak w podejściu do dyplomu rzekomo z 1150 r. nie jesteśmy całkiem pozbawieni możliwości krytyki czy interpretacji, i to na różnych płaszczyznach.

Nie ulega wątpliwości sam fakt wczesnej metryki nadań zawartych w omawianym dokumencie, tj. Kłobii i Chocenia. Obie występują wśród wsi klasztornych pierwszej grupy rzekomego dokumentu fundacyjnego klasztoru w Lądzie ${ }^{10}$. Trzeba dodać, że na obu dokumentach identycznie (choć w nieco innej formie) określono wymiar obowiązków i powinności mieszkańców Kłobii i Chocenia, lecz dokument rzekomo z $1150 \mathrm{r}$. w instruktarzu wymienia ponadto posługi, które rzekomy dokument fundacyjny rozciąga już na ogół mieszkańców wsi klasztornych, oraz oba zawierają jednakowe klauzule immunitetowe ${ }^{11}$. Poza tym Kłobię i Choceń identyfikuje się na Kujawach w pobliżu Włocławka ${ }^{12}$. Powstaje więc pierwszy problem: od kogo pochodzi to nadanie wsi kujawskich klasztorowi lędzkiemu? Fakt tak wczesnego datowania tego falsyfikatu nie pozwala na jednoznaczne odrzucenie możliwości nadań przez Kazimierza Sprawiedliwego. Będąc przeświadczonym o niemałych trudnościach z rozstrzygnięciem postawionego wyżej pytania, spróbuję jednak rozeznać się w możliwościach, jakie się nasuwają. Wydaje się, że problem oznaczenia osoby, od której pochodzą nadania wsi kujawskich, zawęża się do dwóch osób, mianowicie Mieszka III, inicjatora drugiej fundacji lędzkiej, od którego z pewnością pochodzi zasadniczy zrąb nadań uwypuklonych w rzekomym dokumencie fundacyjnym, oraz Kazimierza Sprawiedliwego jako rzekomego nadawcy posiadłości kujawskich opactwa lędzkiego rzekomo z $1150 \mathrm{r}$. Warto przy tym wyjaśnić, dlaczego całą rzecz zawężam do dwóch wymienionych książąt, skoro w literaturze wskazano jeszcze jedną ewentualność. Henryk Waraczewski, zdając sobie wprawdzie sprawę z trudności w precyzyjnym ustaleniu donatora wsi kujawskich klasztorowi lędzkiemu, wysunął hipotezę, widząc w księciu Leszku (synu Bolesława Kędzierzawego) darczyńcę cystersów lędzkich z wsi kujawskich ${ }^{13}$. Pogląd ten nie ma jednak najmniejszego oparcia w źródłach, toteż z miejsca go odrzucam. Sprawę tę mogłoby rozwiązać ustalenie dokładnej daty opanowania Kujaw przez Mieszka III. W historiografii przedstawiano dotąd trzy daty: $1186^{14}, 1191^{15}$

10 KDW, t. 1, nr 393.

11 Oczywiście biorąc pod uwagę dłuższą wersję rzekomego dokumentu fundacyjnego.

12 T. Jurek, Dokumenty fundacyjne..., s. 42.

13 H. Waraczewski, Proces fundacyjny..., s. 162.

14 H. Rutkowski, Zajęcie Kujaw przez Mieszka Starego [w:] S.K. Kuczyński (red.), Społeczeństwo Polski średniowiecznej, t. 5, Warszawa 1992, s. 109-123.

15 Tak głównie w starszej literaturze. Szczegółowy stan badań: ibidem. 
i 1194 r. ${ }^{16}$, przy czym w rachubę mogą wchodzić jedynie lata 1194 i 1186 . Problem w tym, że obie te daty nie mają prawie żadnego oparcia w źródłach. Późniejsze datowanie objęcia rządów na Kujawach przez Mieszka III opiera się jedynie na argumencie ex silentio i wyznacza z jednej strony śmierć Kazimierza Sprawiedliwego, z drugiej - fakt późniejszych rządów Mieszka w tej dzielnicy ${ }^{17}$. Natomiast 1186 - rok śmierci dotychczasowego władcy Kujaw, księcia Leszka - ma według Henryka Rutkowskiego za sobą pośredni argument w datacji listy świadków: falsyfikatu mogileńskiego rzekomo z 1103 r., streszczającego proces o Radziejów prowadzony przez urzędników Mieszka III oraz zapisu kommemoracyjnego z księgi brackiej klasztoru w Lubiniu, które w zasadniczej części są ze sobą zbieżne i wymieniają te same testujące osoby. Warto zauważyć, że datowanie listy świadków dokumentu mogileńskiego na podstawie wyznaczenia datacji opartej na błędzie paleograficznym w zapisce lubińskiej ma tyle samo argumentów za, co i prze$\mathrm{ciw}^{18}$. Jednak przyjęcie tej ostatniej daty całkowicie wyklucza rządy Kazimierza Sprawiedliwego na Kujawach ${ }^{19}$, co wydaje się mało prawdopodobne ze względu na późniejszą tradycję widzącą w księciu Kazimierzu Sprawiedliwym protoplastę linii kujawskiej Piastów ${ }^{20}$.

Nie mogąc rozstrzygnąć tej kwestii, pokuszę się jednak o wyjaśnienie problemu, dlaczego redagując dyplom rzekomo z 1150 r., mnisi lędzcy jako wystawcę podali właśnie księcia Kazimierza. Z moich wcześniejszych uwag nie wynikało bowiem, że niemożliwe byłoby przyjęcie nadania Kłobii i Chocenia od Kazimierza Sprawiedliwego. Niemniej zaznaczę, że datę ewentualnych nadań pochodzących od tego księcia wyznaczały lata: 1186, czyli rok śmierci Leszka, dotychczasowego władcy Kujaw, oraz 1194 - rok śmierci Kazimierza Sprawiedliwego. Rzecz wydaje się więc mniej prawdopodobna, bowiem na ten okres przypada, po pierwsze, konflikt między Mieszkiem III a Kazimierzem Sprawiedliwym ${ }^{21}$, po drugie - kasata klasztoru lędzkiego w początku lat 90. XII w., zaś ponowną fundację opactwa datuje się na lata 1194-119522. Jednak podjęto już w literaturze przedmiotu próbę interpretacji poszukującej na zupełnie innej płaszczyźnie wyjaśnienia okoliczności sfabrykowania przez mnichów lędzkich falsyfikatu na imię Kazimierza Sprawiedliwego niż

${ }^{16}$ S. Szczur, Zmiany polityczne w Wielkopolsce w latach 1181-1195, „Roczniki Historyczne” 1980 , t. 46 , s. $1-15$.

${ }^{17}$ H. Rutkowski, Zajęcie Kujaw...; S. Szczur, Zmiany polityczne...

${ }_{18}$ Tezę H. Rutkowskiego zdaje się jednak akceptować Z. Dalewski, Władza, przestrzeń, ceremoniat. Miejsce i uroczystość inauguracji władcy w Polsce średniowiecznej do końca XIV wieku, Warszawa 1996, s. 84.

${ }^{19}$ Przypomnę, że książę Bolesław Kędzierzawy zapisał synowi Leszkowi Mazowsze wraz z Kujawami. Por. H. Łowmiański, Początki Polski..., s. 142.

20 J. Bieniak, Rola Kujaw w Polsce piastowskiej, „Ziemia Kujawska” 1963, t. 1, s. 30-39.

${ }^{21}$ H. Rutkowski, Zajęcie Kujaw...; S. Szczur, Zmiany polityczne...

${ }^{22}$ T. Jurek, Dokumenty fundacyjne opactwa w Ladzie, ,Roczniki Historyczne” 2000, t. 66, s. 12. 
hipotetycznego poszukiwania okresu, w którym można by było znaleźć możliwość nadań tego czy innego władcy. Mam tu na myśli interpretację zaproponowaną przez Józefa Mitkowskiego na marginesie rozważań nad autentycznością poszczególnych dokumentów Kazimierza Konradowica ${ }^{23}$. Badacz ten, uznawszy dyplom rzekomo z 1150 r. za oczywiste fałszerstwo, wysunął jednak hipotezę objaśniającą okoliczności powstania tego falsyfikatu, rozpatrując go na tle współczesnych wydarzeń z pogranicza wielkopolsko-kujawskiego, tj. wojny toczącej się między Kazimierzem Konradowicem a Bolesławem Pobożnym, która przeszła do historii pod nazwą wojny o Ląd. Ponieważ nie ma tu miejsca na omówienie okoliczności jej wybuchu, ograniczę się do jednego jej aspektu, który zaakcentował w swojej pracy Mitkowski. Zauważył on, że konflikt rozgrywał się pomiędzy dwiema liniami Piastów, wielkopolską i kujawską, a przypomnę, że Bolesław Pobożny był synem Władysława Odonica, wnukiem Odona i prawnukiem protoplasty linii Piastów wielkopolskich Mieszka III. Kazimierz Konradowic natomiast za ojca miał Konrada Mazowieckiego, za dziada zaś Kazimierza Sprawiedliwego. Mając tak zarysowany obraz, Mitkowski stwierdził, że w 1251 r., gdy kasztelania lędzka pozostawała pod rządami Kazimierza Konradowica, mnisi lędzcy, przedstawiając do konfirmacji księciu swe posiadłości kujawskie, celowo sfabrykowali nowy przywilej na imię dziada księcia, który w ówczesnej sytuacji politycznej występował jako prawny sukcesor i w ten sposób manifestował swoje prawa do opieki nad lędzkimi cystersami, więc i prawa do ziemi lędzkiej.

Nie ukrywam, że poza końcowymi przywołanymi przeze mnie wnioskami widzę tu trafne podejście do rozpatrywanego falsyfikatu. Spróbuję zatem zarysować dodatkową możliwość interpretacji. Uważam, że falsyfikat wystawiony rzekomo przez Kazimierza Sprawiedliwego w 1150 r. stanowi dobrą ilustrację tezy Bernarda Guenée ${ }^{24} \mathrm{o}$ ścisłym związku między autorytetem a autentycznością, czy nawet uwierzytelnianiem różnego rodzaju tekstów, w tym dokumentów, w średniowiecznej Europie $^{25}$. Tezy tej starał się bronić Guenée, podając zaczerpnięte z historiografii przykłady powierzania notariuszom publicznym zadania spisania kroniki przez poszczególnych ludzi czy miasta, aby poprzez własny autorytet uwierzytelniali przedstawiane dzieje. Konkluzje artykułu mają jednak znacznie szerszy wymiar, a ostatni przykład przytoczony przez Guenée przedstawia dla mnie szczególną wartość, toteż dłużej się nad nim zatrzymam.

${ }^{23}$ J. Mitkowski, Kancelaria Kazimierza Konradowica..., s. 29-31.

${ }^{24} \mathrm{~B}$. Guenée, Authenthique et approuvé: recherches sur les principes de la critique historique au Moyen Age [w:] I. Lefèvre, La lexicographie du latin médiéval et ses rapports avec les recherches actuelles sur la civilisation du Moyen Age, Paris 1981, s. 215-229.

${ }^{25}$ Tezę B. Guenée zaakceptowali autorzy najnowszego podręcznika dyplomatyki średniowiecznej O. Guyotjeannin, J. Pycke, B.- M. Tock, Diplomatique médiévale, Brepols 1993, s. 367. 
Autor XV-wiecznej kroniki klasztoru w Evesham, Tomasz z Marlborough, przedstawiał historię mającą miejsce w $1205 \mathrm{r}$. W kurii papieskiej toczyła się właśnie sprawa o egzempcję klasztoru w Evesham spod jurysdykcji biskupstwa Worcester. Cała rzecz rozgrywała się przed papieżem Innocentym III, znanym skądinąd jako twórca podstaw krytyki dokumentu ${ }^{26}$. W toku procesu, na udowodnienie swoich praw do egzempcji, ze strony klasztoru zostały przedstawione dwa dokumenty, których wystawcą był sam Konstantyn Wielki. Rzecz się powiodła, mimo protestu obrońcy biskupa, a papież, zapoznawszy się z dokumentami, miał oświadczyć: Istae verae sunt i dalej quum approbata fuerunt, inaestimabili gaudio repletus sum. W celu interpretacji tych słów oddajmy jednak głos samemu Guenée, który pisze: „Le probleme de savoir s'ils étaient vrais ou faux était secondaire, car ils étaient en tout cas approuvés, et par quelle autorité!, et donc authentiques, et donc dignes de foi" ${ }^{27}$.

Choć dysponuję szczątkową literaturą dotyczącą średniowiecznych fałszerstw, nieograniczającą się do badania krytyki autentyczności, wskażę na podobne przykłady mogące posłużyć do interpretacji falsyfikatu rzekomo z $1150 \mathrm{r}$. Michael T. Clanchy, rozpatrując kwestię fałszerstw w średniowiecznej Anglii, odnotował ciekawe zjawisko fabrykowania serii falsyfikatów przez większość instytutów kościelnych w początkach panowania Wilhelma Zdobywcy na imię Edwarda Wyznawcy. I tu interpretacja nasunęła się niejako sama, wszak Wilhelm Zdobywca, legitymując podbój Anglii, ogłosił się prawnym sukcesorem Edwarda ${ }^{28}$. Podobne zjawisko odnotowują Olivier Guyotjeannin, Jacques Pycke i Benoît-Michel Tock ${ }^{29}$, stwierdzając, że zdecydowaną większość falsyfikatów sfabrykowanych w IX-X w. zredagowano na imiona największych Karolingów. Daleko więc tu do ukrytej poza warstwą fałszerstwa prawdy historycznej czy dobrej tradycji.

Powracając $\mathrm{z}$ tak zarysowanym problemem do analizowanego dyplomu wystawionego rzekomo przez Kazimierza Sprawiedliwego, uważam, że mamy tu do czynienia z podobnym zjawiskiem. Cystersi lędzcy, starając się o konfirmację kujawskich posiadłości opactwa u księcia łęczycko-kujawskiego Kazimierza Konradowica, ówczesnego władcy kasztelanii lędzkiej, celowo wystylizowali intytulację dokumentu na imię dziada księcia wówczas panującego, utwierdzając fałszerstwo dokumentu autorytetem księcia Kazimierza Sprawiedliwego, protoplasty linii kujawskiej Piastów. Sprawa rzeczywistego nadawcy nie miała zaś dla żadnej ze stron znaczenia.

Dokument rzekomo z 1150 r. przedstawia dla mnie jednak szczególną wartość z innych względów. Jak się wydaje, instruktarz na dokumencie rzekomo z 1145 r.

\footnotetext{
${ }_{26}$ M.T. Clanchy, From Memory to Written Record. England 1066-1307, Oxford 1993, s. 325.

${ }^{27}$ B. Guenée, Authenthique et approuvé..., s. 227.

${ }_{28}$ M.T. Clanchy, From Memory to Written Record..., s. 318.

29 O. Guyotjeannin, J. Pycke, B.-M. Tock, Diplomatique médiévale, s. 371.
} 
nie jest oddany w swej pierwotnej postaci. Przyjrzę się więc jego rozbiorowi zaproponowanemu przez Stanisława Trawkowskiego w pracy poświęconej gospodarce wielkiej własności cysterskiej na Dolnym Śląsku, która traktowała porównawczo o powinnościach i obowiązkach mieszkańców wsi klasztoru w Lądzie, oraz uwagom Tomasza Gintera ${ }^{30}$. Ponieważ tematem tej pracy nie jest analiza majątku klasztornego ani gospodarki cystersów lędzkich, skoncentruję się na tych częściach instruktarza dokumentu rzekomo z 1150 r., które różnią się od swych odpowiedników z rzekomego dokumentu fundacyjnego ${ }^{31}$.

Warto odnotować, że wymiar obowiązków i powinności przekazanych w instruktarzu na obu dokumentach jest taki sam i dotyczy mieszkańców tych samych wsi klasztornych ${ }^{32}$. Różnica polega na kolejności wymienianych danin i powinności oraz formie zapisu obowiązku dostarczania przez mieszkańców klasztornych miary pszenicy, ścięcia na dzień świętego Michała sześćdziesięciu snopków żyta. Dokument rzekomo z $1150 \mathrm{r}$. wymienia ponadto w instruktarzu obowiązek noszenia listów klasztornych.

Oto zapisy obu dokumentów:

1145

Istarum ergo villarum homines tenentur solvere pro festo s. Michaelis LX manipulos silignis, modium avenae, mensuram tritici, tres urnas brasei, quinque capetia annonae metere, duo plaustra foeni totidemque lignorum, duos trochos de pino, per tres continuos dies cum tota familia segetes purgare, per unum diem singuli cumulare, tres kitas lini dare.
1150 ...predictarum villarum homines in subsidium prenominatorum fratrum annuatim solvere tenentur LX a manipulos nove silignis, quinque capecia annone metere, tribus diebus segetes purgare, per unum diem triturare, rete trhere, in festo sancti Michaelis modium avene, pro tribus panibus mensuarum tritici, tres urnas brasii, tres chitas lini, tres plaustratas feni totidemque lignorum, duos truncos de pino, et cum necessitas fratrum exegerit, tam pedestres quam equestres mandato eorum dirigere.

Tomasz Ginter na podstawie analogii uznał powstanie instruktarza w XII w. za mało prawdopodobne i datował go na następne stulecie ${ }^{33}$. Zauważył też, że termin

${ }^{30}$ S. Trawkowski, Gospodarka wielkiej własności cysterskiej..., s. 111-113; T. Ginter, Działalność fundacyjna ..., s. 110-114.

${ }_{31}$ KDW, t. 1, nr 393 oraz T. Jurek, Dokumenty fundacyjne..., nr 1.

${ }^{32}$ Kłobia i Choceń, nadane rzekomo przez Kazimierza Sprawiedliwego w 1150 r., należą do pierwszej grupy wsi klasztornych rzekomego dokumentu fundacyjnego opactwa w Lądzie. Zob. KDW, t. 1, nr 393.

${ }^{33}$ T. Ginter, Działalność fundacyjna ..., s. 110-112. 
składania danin jest nieco inny na falsyfikacie dokumentu Kazimierza Sprawiedliwego niż na dokumentach datowanych na $1145 \mathrm{r} .{ }^{34}$ Passus o ciągnieniu sieci pomiędzy Sieradzem a Włocławkiem zinterpretował jako prawo połowu ryb na tym terytorium i odrzucił pogląd T. Jurka o archaiczności tego zapisu ze względu na brak możliwości dokonania takiego nadania przez Mieszka III. Uznał przy tym, że nadanie musiało być dokonane przez Kazimierza Konradowica, ale powinności obecne na instruktarzu dokumentów datowanych na 1145 i 1150 r. różnią się i zmieniają na kolejnych egzemplarzach dokumentu fundacyjnego klasztoru w Lądzie ${ }^{35}$.

$\mathrm{Z}$ kolei S.Trawkowski na podstawie dokumentu rzekomo z 1150 r., poddając analizie powyższy wykaz obowiązków i powinności mieszkańców wsi klasztoru w Lądzie, wyróżnił cztery ich grupy ${ }^{36}$. Pierwsza obejmowała robocizny związane z gospodarką własną klasztoru, do której zaliczył obowiązek zżęcia pięciu kop zboża, pielenia trzy dni zasiewów oraz jeden dzień pracy przy młócce. Drugą stanowiły świadczenia zreluowanych dawnych ciężarów prawa książęcego, w tym obowiązki dostarczania korca owsa, miary pszenicy zamiast trzech chlebów, trzech garnców słodu, trzech kit lnu, trzech wozów siana, tyleż drewna opałowego oraz dwóch pni sosnowych. Trzecią tworzyła renta naturalna, czyli w tym wypadku obowiązek ścięcia sześćdziesięciu nowej miary snopków żyta. Czwartą grupę stanowiły zaś posługi, tj. obowiązek noszenia listów klasztornych. Nie zagłębiając się w rozbiór instruktarza czy weryfikację propozycji podziału obowiązków i powinności pióra Trawkowskiego, skoncentruję się na różnicach w zapisie obu dokumentów zreluowanych obowiązków mieszkańców wsi klasztornych. Jak już wspomniałem, w odmienny sposób oddany jest jedynie zapis obowiązku dostarczania miary pszenicy, który na dokumencie rzekomo z 1150 r. opatrzony jest dodatkową informacją: zamiast trzech chlebów, oraz zapis obowiązku zżęcia sześćdziesięciu snopków zboża, który na dokumencie rzekomo z 1150 r. oddany jest w formie rozszerzonej - informuje o liczbie snopków, ale nowej miary. Trawkowski, rozpatrując obie wzmianki, słusznie zauważył, że nie powtarzają się one na żadnym innym dokumencie lędzkim, i - podkreślę - nie ma ich także na rzekomym dokumencie fundacyjnym, i to na żadnej z jego wersji ${ }^{37}$. Interpretacja rozszerzonych zapisów dokumentu rzekomo z 1150 r. wskazuje jednoznacznie na zamianę świadczeń. Z obliczeń Trawkowskiego wynika bowiem, że mieszkańcy pierwszej grupy wsi klasztornych mieli oddawać corocznie 29 września 150 chlebów, co wydaje się mało prawdopodobne, jeśli danina ta miała być uiszczana mnichom lędzkim, zrozumiała zaś przy okazji wybierania stanu przygodnego. Co

${ }^{34}$ Ibidem, s. 112.

${ }^{35}$ Ibidem, s. 114.

${ }^{36} \mathrm{~W}$ tym miejscu podążam za S. Trawkowskim, Gospodarka wielkiej własności cysterskiej..., s. $132-138$.

${ }^{37} \mathrm{KDW}$, t. 1, nr 393; T. Jurek, Dokumenty fundacyjne..., nr 1. 
więcej, przy takiej interpretacji zrozumiały staje się sam zapis zreluowanej formy, tj. przekazanie dawniej pobieranej daniny przez księcia bądź jego urzędników nie w pierwotnej formie, zupełnie bezużytecznej dla instytutu kościelnego, lecz w nowej, dostosowanej do potrzeb instytucji, która ma daną daninę pobierać. Podobnie można interpretować zapis liczby snopków nowej miary jako składnik dawniejszego systemu ciężarów książęcych przekazanych klasztorowi w zamienionej już formie ${ }^{38}$. $Z$ tego również wynika, że samej zamiany świadczeń $w$ obu wymienionych wypadkach musiał dokonać książę.

Obie omówione formy zapisów z dokumentu rzekomo z $1150 \mathrm{r}$. wydawały się Trawkowskiemu do tego stopnia niezwykłe, że uznał je za przejątek ze sformułowania XII-wiecznego, z czego wyciągnął moim zdaniem zbyt daleko idące wnioski. Uznał bowiem, że mnisi lędzcy w 1251 r. przedstawili do konfirmacji księciu Kazimierzowi Konradowicowi nie falsyfikat, a jedynie dokument interpolowany. Badaczowi temu wydało się bowiem niemożliwe, by mnisi, fabrykując dokument, wprowadzili doń niejasne sformułowanie: LX manipulos nove silignis, które od razu budziło wątpliwości, ponieważ nie było jasne, o jaką nową miarę może chodzić. Uznał, że należałoby się raczej spodziewać określenia liczby snopków nie nową miarą, która stałaby się zrozumiała w przypadku podniesienia świadczenia, lecz według nazwy, np. biskupią, targową, wrocławską. Umieszczanie zaś podobnego sformułowania w fabrykacie XIII-wiecznym traciło wszelki sens, podobnie jak zapisu mensuarum tritici pro tribus panibus ${ }^{39}$.

Przyjmując wywód Trawkowskiego co do archaicznej formy zapisu i mając już przygotowany grunt w postaci krytyki obu wersji rzekomego dokumentu fundacyjnego ${ }^{40}$, przedstawię jednak odmienne zdanie. Przede wszystkim nie zgadzam się z poglądem, że w 1251 r. konfirmowano jedynie dokument interpolowany, a nie falsyfikat. $Z$ wywodu Trawkowskiego nie wynika bowiem, na czym ta interpolacja miałaby polegać, i od razu nasuwa się pytanie, które jego partie są interpolowane, a które stanowią autentyczny zrąb dokumentu? Tego jednak badacz w swojej rozprawie nie wykazał. Odrzucił możliwość wczesnej datacji dyplomu, nie wykazując, że nadanie Kłobii i Chocenia pochodzi dowodnie od Kazimierza Sprawiedliwego, oraz przyjmując zwiększony wymiar obciążeń mieszkańców klasztoru, z dwóch dostarczanych wozów siana do trzech na podstawie krótszej wersji rzekomego dokumentu fundacyjnego, czyli dokonując zabiegu, jak łatwo to

${ }^{38}$ Por. przykład dokumentu fundacyjnego klasztoru w Trzebnicy oraz pracę R. Grodeckiego, Książęca włość trzebnicka na tle organizacji majątków książęcych w Polsce XII wieku, „Kwartalnik Historyczny" 1913, t. 27, s. 22-24. Na temat zamiany świadczeń: J. Widajewicz, Danina stolu ksiażęcego w Polsce piastowskiej, Lwów 1926, s. 54.

${ }^{39}$ Podobnie T. Ginter, Działalność fundacyjna ..., s. 113.

${ }^{40}$ M. Pytel, Uwagi nad przekazem dokumentu fundacyjnego klasztoru cystersów w Ladzie, „Czasopismo Prawno-Historyczne” 2020, t. 72, nr 1. 
wcześniej wykazano, dowolnego. Warto zauważyć, że idąc tokiem rozumowania Trawkowskiego, nie można zauważyć interpolowanych partii dokumentu ${ }^{41}$. Fakt, że dokument rzekomo z 1150 r. zawiera archaiczne sformułowania, podobnie jak argument o wyrobieniu w pracy nad dokumentem mnichów lędzkich, nie rozstrzyga sprawy, wręcz przeciwnie - nasuwa zupełnie inne rozwiązanie.

Zanim przejdę do jego rozbioru, zatrzymam się na drugiej różnicy między instruktarzem dokumentu rzekomo z $1150 \mathrm{r}$. a rzekomym dokumentem fundacyjnym klasztoru w Lądzie. Chodzi o obowiązek mieszkańców wsi opactwa noszenia listów klasztornych pieszo lub konno, który na dokumencie rzekomo z 1150 r. wymienia instruktarz, a który na rzekomym dokumencie fundacyjnym wymieniony jest zaraz po wykazie wsi klasztornych drugiej grupy ${ }^{42}$. Czy mnisi lędzcy rozciągnęli więc omawiany obowiązek na mieszkańców Kłobii i Chocenia, fabrykując dokument rzekomo z 1150 r., czy może dopiero redagując rzekomy dokument fundacyjny na potrzeby konfirmacji z 1261 r., przerzucili obowiązek noszenia listów klasztornych, dodając powinność ciągnienia sieci pomiędzy Włocławkiem a Sieradzem poza wykaz nadanych klasztorowi wsi, wyznaczając tym samym dodatkowe obowiązki wszystkim mieszkańcom wsi opactwa lędzkiego? A może na rzekomym dokumencie fundacyjnym określały one jedynie obowiązki mieszkańców drugiej grupy wsi opactwa? Charakterystyczne, że Władysław Łokietek w trakcie procesu klasztoru z mieszkańcami Dolan zażądał od opata Lądu przedstawienia dokumentu fundacyjnego, po czym dopiero wydał wyrok, m.in. wymieniając obowiązki i powinności mieszkańców tej wsi i powtarzając ich wymiar za instruktarzem rzekomego dokumentu fundacyjnego, jednakże dodając obowiązek noszenia listów klasztornych. Mogłoby to wskazywać na kierunek zwiększania powinności mieszkańców wsi opactwa lędzkiego, obciążanie mieszkańców pierwszej grupy wsi klasztornych powinnościami drugiej.

Jednakże na ustalenie chronologii rzekomo najwcześniejszych dokumentów lędzkich oraz podstawy, na jakiej oparł się obecnie rozpatrywany falsyfikat, przyjęcie tego czy innego rozwiązania nie ma najmniejszego wpływu, ponieważ nie znamy instruktarza w jego pierwotnej postaci, a nie jest nim instruktarz znany z rzekomego dokumentu fundacyjnego, ponieważ nie zawiera oczywistych archaizmów instruktarza dokumentu rzekomo z 1150 r. Jednakże dalej nie wiadomo, czy i ten zachował się w swej pierwotnej postaci, gdyż wzmianka o powinnościach mieszkańców Kłobii i Chocenia noszenia listów klasztornych wydaje się właśnie interpolacją, ale w ramach samego instruktarza. Ponieważ dokument rzekomo z 1150 r. powtarza zasadniczo tekst za rzekomym dokumentem fundacyjnym, do-

${ }^{41}$ Jeżeli tak stawiać sprawę, to można byłoby się doszukiwać interpolacji w klauzuli immunitetowej dokumentu, czego jednakże S. Trawkowski nawet nie zauważa. Por. S. Trawkowski, Gospodarka wielkiej wtasności cysterskiej..., s. 111-113.

${ }^{42}$ KDW, t. 1, nr 393. 
tyczy zaś dwóch wsi, które odnajduję też na rzekomym dokumencie fundacyjnym pośród wsi klasztornych pierwszej grupy, rodzi się pytanie, czy dokumentu z $1150 \mathrm{r}$. nie sfabrykowano na podstawie wcześniejszego dokumentu fundacyjnego? To, iż rzekomy dokument fundacyjny w formie znanej obecnie nie ma archaicznie wystylizowanego instruktarza, nie może przemawiać za tym, że dokument z $1150 \mathrm{r}$. nie opierał się na dokumencie fundacyjnym opactwa, bo nie można być pewnym, czy egzemplarz włocławski jest - jak chce tego T. Jurek - autentycznym przywilejem fundacyjnym klasztoru, czy jedynie nowożytnym odpisem. Podobnie jak nie wiadomo, czy egzemplarz koloński rzekomego dokumentu fundacyjnego opiera się na autentycznym dokumencie Mieszka III ${ }^{43}$, a może raczej w której części jest oparty na XII-wiecznym autentyku lędzkim. Wiadomo bowiem, że formularz protokołu oraz narracji dokumentu zredagowano w Lubiążu, i to niekoniecznie na podstawie autentyku z 1175 r. ${ }^{44}$ Co więcej, rozbiór formularza najstarszych dokumentów dyktatu cystersów lędzkich może utwierdzić wkrótce w tych wątpliwościach. Mając z kolei na względzie czas potwierdzeń dokumentu rzekomo z 1150 r. - 1251 r. oraz egzemplarza kolońskiego - 1261 r., nietrudno wythumaczyć różnicę w zapisach form instruktarza na obu dokumentach. W $1251 \mathrm{r}$. fabrykując dokument rzekomo z 1150 r., oparto się na jakimś wcześniejszym, XII-wiecznym dokumencie, przepisując zeń literalnie tekst, przynajmniej w części koniecznej do zredagowania dyplomu (stąd archaiczne zwroty) być może w niewielki sposób go interpolując. Odwracając rozumowanie Trawkowskiego, łatwo teraz wytłumaczyć, że jeśli niezrozumiałe wówczas sfomułowania dokumentu rzekomo z 1150 r. budziły różne wątpliwości, to redagując następny dokument, je usunięto ${ }^{45}$.

Rozpatrując dokument z 1150 r., prawie wszyscy jego badacze ograniczali się do ewidentnego stwierdzenia fałszerstwa, nie wgłębiając się w rozbiór dyplomu. Wynikało to niewątpliwie z faktu, że dokument z 1150 r. zachował się jedynie $\mathrm{w}$ transumpcie, który podaje jedynie dyspozycję dokumentu potwierdzanego, pomija zaś wszystkie formuły dyplomatyczne. Sprawa jednak wcale nie wygląda tak źle, jakby na pozór się mogło wydawać.

Na początek powrócę do dokumentu rzekomo wystawionego przez Kazimierza Sprawiedliwego w 1150 r. i jego transumptu z 1251 r. Rzekomy dyplom Kazimierza Sprawiedliwego zachował się jedynie w dyspozycji, pozbawiony jest natomiast wszelkich formuł dyplomatycznych poza nią. Ponadto jego transumpt - dokument Kazimierza Konradowica - zredagowali cystersi lędzcy. Zasadne jest więc pytanie o metody pracy w klasztorze lądzkim nad redakcją transumptów.

${ }^{43}$ M. Pytel, Uwagi nad przekazem...

${ }^{44}$ W. Kętrzyński, Studia nad dokumentami..., s. 85.

${ }^{45}$ Podobnie T. Ginter uznaje czas powstania instruktarza na ok. połowę XIII w. Zob. T. Ginter, Działalność fundacyjna..., s. 114-115. 
Z XIII w. zachowały się cztery transumpty dokumentów opactwa w Lądzie, przy czym wszystkie z nich zredagowano w klasztorze. Są to następujące dokumenty: (1) będący przedmiotem rozważań rzekomy dokument Kazimierza Sprawiedliwego z 1150 r., (2) potwierdzony w 1251 r. przez Kazimierza Konradowica, (3) rzekomy dokument fundacyjny konfirmowany w 1261 r. przez Bolesława Pobożnego, a w 1280 r. przez Przemysła II, (4) dokument Mściwoja z 1280 r., potwierdzony w 1291 r. również przez Przemysła II ${ }^{46}$. Jedynie dokument Mściwoja z 31 lipca 1280 r. przytoczono w całości, redagując jego potwierdzenie ${ }^{47}$. Trzy pozostałe konfirmacje przytaczają jedynie dyspozycje potwierdzanych dokumentów, a ponieważ dwukrotnie potwierdzano rzekomy dokument fundacyjny klasztoru w Lądzie, którego tekst znamy w całości, można doszukiwać się analogii i przy redakcji transumptu dokumentu rzekomo Kazimierza Sprawiedliwego z 1150 r.

Transumpt Bolesława Pobożnego wystawiony w Szetlewie 10 grudnia $1261 \mathrm{r}$. zawiera inwokację: In nomine sancte et individue Trinitatis amen, która ma wyjątkową formę, ponieważ spośród dokumentów dyktatu lędzkiego znajduje się jedynie na rzekomym dokumencie fundacyjnym, który w protokole i narracji opiera się na dokumencie fundacyjnym klasztoru w Lubiążu i jego falsyfikatach oraz na dokumencie zredagowanym pięć miesięcy po pierwszej konfirmacji rzekomego dokumentu fundacyjnego, 24 kwietnia 1262 r. $^{48}$, ale w pewnej odmianie, albowiem słowo sanctus oddane jest w stopniu najwyższym i inwokacja brzmi: In nomine sanctissime et individue Trinitatis amen. Arenga: Quoniam factum omne modernorum haberi solet dubium quod non litterarum apicibus roboratur została dosłownie przeniesiona z dokumentu Kazimierza Konradowica z 1250 r. Promulgacji dokument Bolesława Pobożnego nie posiada. Korroboracja: Ut autem hoc nostrum factum in honorem Dei sancteque genitricis eiusdem semperque virginis Marie ratum inviolabiliter observetur, presentem cedulam sigilli nostri munimine duximus roborandam jest najczęściej stosowaną korroboracją na dokumentach klasztoru w Lądzie, ale dokładnie tę samą formę korroboracji zawiera też rzekomy dokument fundacyjny, a należy ona już niewątpliwie do partii dokumentu zredagowanej w Lądzie ${ }^{49}$. Klątwy dokumentu: (ita videlicet) ut si quod absit, aliquis posterorum nostrorum vel eciam alienorum huic, nostro facto ausu temerario contraire presumpserit, indignacionem Dei omnipotentis nec non beatorum apostolorum Petri et Pauli atque omnium sanctorum se noverit incursurum $\mathrm{w}$ tej formie nie można już wprawdzie odnaleźć na żadnym pozostałym dyplomie dyktatu cystersów

${ }^{46}$ KDW, t. 4, nr 2057 (496a) i jego transumpt KDW, t. 6, Warszawa - Poznań 1982, nr 41.

${ }^{47}$ Iussimus igitur nobis presentari privilegium prefati ducis Mestwini, quod oculata fide perspeximus non cancellatum, non abolitum nec aliqua parte viciatum, cuius tenorem de verbo ad verbum presentibus duximus inserendum.

$48 \mathrm{KDW}, \mathrm{t} .1$, nr 395.

49 Ibidem, nr 393; T. Jurek, Dokumenty fundacyjne..., nr 1. 
lędzkich, jednak maledykcja pojawia się również na niedatowanym falsyfikacie dokumentu Bolesława Pobożnego z 13 listopada 1255 r. wraz ze zmienioną korroboracją swego wzoru $^{50}$, a w formie spotykanej m.in. na rzekomym dokumencie fundacyjnym. Użycie określenia anno Domini na dyplomie z 1261 r. jest najczęstszym sposobem oznaczania roku również na pozostałych dyplomach lędzkich ${ }^{51}$. Data dzienna oddana za pomocą kalendarza rzymskiego, poza falsyfikatami, jest zaś wyłącznym sposobem oznaczania dnia na dokumentach opactwa lędzkiego do 1262 r. ${ }^{52}$ Formuła świadków: Adest et fidelium testium astipulacio pojawia się natomiast na dokumentach redagowanych w klasztorze w Lądzie od lat 60. aż do połowy lat 80 . XIII w. ${ }^{53}$ Nie wyciągając na razie wniosków, przytoczę jeszcze teksty dokumentu potwierdzającego Przemysła II oraz potwierdzanego rzekomego dokumentu fundacyjnego, ale pominę dyspozycję i świadków obu dyplomów.

Jak łatwo się przekonać, formularz dokumentu potwierdzającego jest całkowicie oparty na formularzu dokumentu potwierdzanego. Nie dość, że powtórzono $\mathrm{w}$ prawie niezmienionej formie arengę, promulgację, korroborację ${ }^{54}$, to omal niezmieniona pozostała narracja dokumentu potwierdzanego, która została jedynie nieznacznie skrócona i dostosowana do potrzeb formy transumptu. Do zmian, jakie wprowadzono do tekstu konfirmacji w porównaniu z tekstem rzekomego dokumentu fundacyjnego, należą przede wszystkim zmiana inwokacji na najbardziej rozpowszechnioną w dokumentach dyktatu lędzkiego formułę świadków oraz dodanie formuły datum per manus notariusza książęcego, który spisał dokument ${ }^{55}$.

Jeśli chodzi o formularz dokumentu Kazimierza Konradowica, to inwokacja: In nomine Domini amen, choć jest w tej formie najbardziej powszechna w XIII w., stanowi, z trzema drobnymi wyjątkami, stały element formularza dokumentów opactwa w Lądzie. Arenga: Omnis actio legitima, memoria indigens, ne pravorum hominum suggestionibus infirmetur, utile et cautum est ut scripture testimonio roboretur według Karola Maleczyńskiego ${ }^{56}$ poza dokumentami dyktatu cystersów lędzkich nie występuje na żadnym dokumencie z ziem polskich, przynajmniej do

${ }^{50} \mathrm{KDW}$, t. 1, nr 600.

${ }^{51}$ Ibidem, nr 10, 20, 26, 27, 28, 80, 192, 395 i n.

${ }^{52}$ Ibidem, nr 80, 192, 331. Z kolei nr 298 nie ma oznaczenia daty dziennej. Jednak falsyfikat z początku lat 40. XIII w., dokument wystawiony rzekomo przez księcia Mieszka III w 1181 r., ma datę dzienną oddaną już za pomocą kalendarza kościelnego. Zob. T. Jurek, Dokumenty fundacyjne..., s. 43.

${ }_{53}$ M. Pytel, Falsyfikaty dokumentowe klasztoru cystersów w Lądzie do końca XIII wieku (niepublikowana praca magisterska), Lublin 2001.

${ }^{54}$ Dostosowaną jedynie do tekstu dyplomu konfirmującego.

${ }_{55}$ Pomijam tu z oczywistych względów zmianę wystawcy oraz daty dokumentu.

${ }^{56}$ K. Maleczyński, O formularzach w Polsce w XIII wieku [w:] idem, Studia nad dokumentem polskim, Wrocław 1971, s. 195-196, przyp. 35. Warto zauważyć, że T. Nowakowski nie odnajduje tej arengi wśród areng zredagowanych do połowy XIII w. Zob. T. Nowakowski, Idee areng dokumentów książat polskich do połowy XIII wieku, Bydgoszcz 1999. 
1145

In nomine Sancte et individue Trinitatis amen.

Quoniamquidem velocitate dierum nostrorum transituri sumus, quemadmodum fugere solet umbra vel evanescere fumus

Igitur nos Mesico Dei gracia dux Polonie

Universis christifidelibus tam presentibus quam futuris notum esse cupimus,

Quod pro dilectione domini nostri Ihesu Christi liberatoris animarum nostrarum et pro veneracione gloriose genitricis eiusdem, perpetue virginis marie et omnium sanctorum monachos Cisterciensis ordinis de longinquis partibus terre adductos, de cenobio videlicet Bergensi, pro viris litteratis, divinorum celebratoribus celestiumque contemplatoribus collocavimus in loco, qui vocatur Lenda, super fluvium Wartam, ob remedium anime nostre ac posterorum nostrorum conferentes eis has hereditates subscriptas cum hominibus et cum omnibus utilitatibus, que in eis sunt ac in posterum provenire poterunt, in nostra eos defensionem suscipientes et successoribus nostris per omne tempus defendendos commitimus solo divine remuneracionis intuitu. Iam vero subnotantur possessionum loca, s(c)ilicet:...

Ut autem hoc nostrum factum ad honorem Dei sancteque genitricis eiusdem semper virginis Marie robur perpetue firmitatis obtineat, presentem cedulam sigilli nostri simul et annuli munimine duximus roborandam. Acta sunt hec in Gnezsene in die beati Adalberti anno Domini M. C. XL.V. indictione nona, epacta vero sexta, presentibus viris ecclesiasticis, videlicet ... et aliis quampluribus nobilibus.
1150

In nomine domini amen.

Quoniam quidem velocitate dierum nostrorum transituri sumus, quemadmodum fugere solet umbra vel euanescere fumus,

Igitur nos secundus Premisl, dei gracia dux Polonie,

Universis Christifidelibus tam presentibus quam futuris notum esse cupimus,

Quod pro dilectione domini nostri Ihesu Christi liberatoris animarum nostrarum, et pro veneracione gloriose genitricis eiusdem, perpetue virginis Marie, et omnium sanctorum innouamus dilectis in Christo fratribus, in domo Lendensi domino famulantibus, priuilegium gloriosi proavi nostri, domini ducis Polonie Mezeconis, confirmantes prefatis fratribus has hereditates subscriptas cum hominibus et omnibus utilitatibus, que in eis sint ac in posterum prouenire poterunt, in nostra eos defensione suscipientes et successoribus nostris per omne tempus defendentes commitimus solo diuine remuneracionis intuitu. Iam vero subnotantur possessionum loca: scilicet ...

Ut autem hec nostra confirmacio ad honorem dei sancteque genitricis eiusdem semper virginis Marie robur perpetue firmitatis obtineat, presentem cedulam sigilli nostri munimine duximus roborandam.

Acta sunt hec in Kalis, in die sancti Luce Ewangeliste, anno domini MCCLXXX presentibus hiis testibus: videlicet ... et data per manus Thilonis, notarii curie nostre. 
końca XIII w. Jednocześnie poza omawianym dokumentem znajduje się na pięciu dokumentach dyktatu lędzkiego ${ }^{57}$, a tym samym jest arengą najczęściej używaną w klasztorze. Promulgacja: notum esse volumus tam presentibus quam posteris w analogicznej formie, choć nieco zmodyfikowana, znajduje się na wcześniejszym fabrykacie klasztornym, falsyfikacie opatrzonym datą 1181 r., a następnie trafia jeszcze do dwóch dokumentów zredagowanych w opactwie lędzkim ${ }^{58}$, w tym do jedynego w XIII w. dokumentu opackiego ${ }^{59}$. Korroboracja: Ut autem hoc nostrum factum in honore Dei sancteque Marie genitricis eiusdem ratum ac firmum permaneant imperpetuum, presentem cedulam sigilli nostri appensione duximus roborandam stanowi korroborację najczęściej używaną w klasztorze w Lądzie, zaopatrzono w nią aż osiem dokumentów, które wyszły spod pióra mnichów lędz$\mathrm{kich}^{60}$. Datacja dyplomu pozbawiona daty dziennej oraz określenie roku mianem anno gracie występuje tylko na dwóch kolejnych dyplomach zredagowanych w klasztorze w Lądzie ${ }^{61}$, niewątpliwie pod wpływem dyplomu z 1250 r., bowiem wszystkie pozostałe XIII-wieczne dokumenty klasztorne ${ }^{62}$ mają rok określony jako anno Domini. Formuła świadków brzmi lapidarnie: presentibus i w podobnej formie znajduje się, oprócz rzekomego dokumentu fundacyjnego, na dyplomach dyktatu lędzkiego dopiero z lat 80., a przede wszystkim z ostatniej dekady XIII w. ${ }^{63}$

Transumpt Kazimierza Konradowica zawiera zatem większość formuł typowo lędzkich, przede wszystkim arengę i korroborację, a przy tym najczęściej używanych w klasztorze lędzkim. Mając także na względzie to, że potwierdzany dokument rzekomo Kazimierza Sprawiedliwego z 1150 r. zawiera archaiczne, najpewniej XII-wieczne sformułowania, oraz przykład redakcji transumptu z 1280 r., jak również analogicznych konfirmacji Leszka Czarnego dokumentów klasztornych Koprzywnicy oraz Wąchocka, których dyktat wprawdzie przypisuje się kancelarii książęcej, ale które w całości opierały się na tekstach dokumentów potwierdzanych ${ }^{64}$, można postawić hipotezę, że formularz dokumentu Kazimierza Konradowica w dużym stopniu odzwierciedla formularz dokumentu potwierdzanego rzekomo przez Kazimierza Sprawiedliwego, który będąc oczywistym fałszerstwem, musiał się jednak

${ }^{57}$ KDW, t. 1, nr 331, 600; KDW, t. 2, nr 695, 707; KDW, t. 4, nr 2057 (496a), choć tu w pewnej odmianie: Omnis ordinatio moderna, providentia indiget et cautela, ne longinquitate temporis vel malorum hominum malicia infirmetur.

${ }^{58} \mathrm{KDW}$, t. 1, nr 476; KDW, t. 6, nr 35.

${ }^{59} \mathrm{KDW}, \mathrm{t} .6, \mathrm{nr} 35$.

${ }^{60} \mathrm{KDW}$, t. 1, nr 10, 26, 393, 395, 440, 600; KDW, t. 2, nr 678, KDW, t. 6, nr 27.

${ }^{61} \mathrm{KDW}, \mathrm{t} .1, \mathrm{nr} 298,331$.

${ }_{62}$ M. Pytel, Falsyfikaty dokumentowe...

${ }^{63}$ Ibidem.

${ }^{64}$ Z. Mazur, Studia nad kancelaria księcia Leszka Czarnego, Wrocław 1975, s. 137-140; Z. Kozłowska-Budkowa, S. Szczur, Dzieje opactwa cystersów w Korzywnicy do końca XIV wieku, „Nasza Przeszłość” 1983, t. 60, s. 28-19. 
oprzeć na jakimś wcześniejszym wzorze. Hipotezy tej nie wydaje się osłabiać nawet redakcja formularza transumptu z 1261 r., bo choć dokument Bolesława Pobożnego nie został w całości oparty na formularzu rzekomego dokumentu fundacyjnego, to przejmuje zeń poszczególne formuły, mianowicie inwokację i korroborację.

\title{
A FORGERY OF A DOCUMENT FROM 1150 AND ITS TRANSUMPT FROM 1251
}

\begin{abstract}
The article is devoted to a forgery from Ląd dated 1150 as well as to its transumpt which was issued in 1251 . The author maintains that the document dated 1150 is a forgery and that its transumpt is authentic. Furthermore, it is the author's opinion that Prince Casimir's name, which the forgery is signed with, was not accidental as it was connected with idea of authority in the Middle Ages, which was used to authenticate documents. Moreover, the forgery under discussion contains archaic phrasing in the so-called duties and obligations' instruction for the citizens of the monastery villages, which are older than the ones known from the alleged founding document of the abbey. On the other hand, an analysis of the form of transumpts edited in the abbey in Ląd leads one to the conclusion that, even though the forgery dated 1150 was devoid of the majority of diplomatic phrases, it contained analogous expressions to the transumpt.
\end{abstract}

Keywords: forgery, diplomatics, examination of authenticity in the Middle Ages, war for Ląd 